\title{
Antimicrobial activity of some plant materials used in Armenian traditional medicine
}

\author{
Mikayel Ginovyan, Margarit Petrosyan and Armen Trchounian*
}

\begin{abstract}
Background: Antibiotic resistance has become one of the major problems facing humanity. The need for new antimicrobials has been increased dramatically. Plants are considered as one of the most promising sources for new antimicrobials discovery. Despite relatively small area, Armenia has large diversity of flora with many endemic species. In Armenian folk medicine plant materials have been used to treat various microbial diseases since ancient times. The goal of our research was to evaluate antimicrobial efficiency of different parts of five wild plants species which are commonly used in Armenian traditional medicine.

Methods: Plant crude extracts were obtained with maceration technique using five solvents separately: distilled water, methanol, chloroform, acetone, and hexane. Agar well diffusion assay was used for initial evaluation of antimicrobial properties of plant materials against five bacterial and two yeast strains. Minimum inhibitory concentrations of the most active plant parts were determined by broth microdilution method.

Results: Crude extracts of all five tested plants expressed antimicrobial activity against at least four test strains at $500 \mathrm{~g} \mathrm{ml}^{-1}$ concentration. Minimum inhibitory and bactericidal/fungicidal concentrations of selected plant parts were determined. Crude acetone and hexane extracts of Hypericum alpestre and acetone extract of Sanguisorba officinalis inhibited the growth of $P$. aeruginosa even at $64 \mathrm{\mu g} \mathrm{ml}^{-1}$ concentration. Chloroform and acetone extracts of Sanguisorba officinalis exhibited cidal activity against $P$. aeruginosa till $256 \mathrm{\mu g} \mathrm{ml}^{-1}$. Acetone was the most effective solvent for solubilizing antimicrobial compounds for almost all tested plant materials.
\end{abstract}

Conclusions: Thus, antimicrobial activity of some medicinal plants used in Armenian traditional medicine was evaluated. Some of the plants had rather low minimum bacteriostatic/bactericidal concentrations and therefore they have prospective for further more inclusive studies.

Keywords: Plant material, Armenian folk medicine, Antibiotic resistance, Crude extract, Antimicrobial activity, Minimum bactericidal concentration, Acetone

\section{Background}

The prevalence of microbial infectious diseases and their complications are continuously increasing throughout the world mainly due to microbial drug resistance toward commonly used antimicrobials [1]. Antibiotic resistance has become one of the major problems of humanity since late $20^{\text {th }}$ century. The need for new antimicrobials, which could effectively fight against resistant

\footnotetext{
* Correspondence: Trchounian@ysu.am

Department of Microbiology, Plants and Microbes Biotechnology, Faculty of Biology, Yerevan State University, 1 Alex Manoogian Str., Yerevan 0025,
} Armenia

(c) The Author(s). 2017 Open Access This article is distributed under the terms of the Creative Commons Attribution 4.0 International License (http://creativecommons.org/licenses/by/4.0/), which permits unrestricted use, distribution, and reproduction in any medium, provided you give appropriate credit to the original author(s) and the source, provide a link to the Creative Commons license, and indicate if changes were made. The Creative Commons Public Domain Dedication waiver (http://creativecommons.org/publicdomain/zero/1.0/) applies to the data made available in this article, unless otherwise stated. proaches to find new antimicrobial drugs are not sufficiently successful anymore due to the rapid resistance development against them [2]. Consequently, it is very important to find new approaches of antimicrobial compounds discovery. Plant materials are demonstrated to be one of the most promising sources [2-4]. Plantderived antimicrobials are also considered to be safer compared with synthetic compounds because of their natural origin $[5,6]$. It is well known that about quarter part of current medications is derived from compounds of plant origin [1,7]. Plant-derived compounds could 
have other target sites than traditional antimicrobials and subsequently having different mechanisms of action against microbes $[6,8-10]$.

Plant secondary metabolites are mostly responsible for their antimicrobial activity [4]. Major groups of phytochemicals which possess antimicrobial properties are phenolics and polyphenols (flavonoids, quinones, tannins, coumarins), terpenoids, alkaloids, lectins and polypeptides $[3,4,6]$. There are several mechanisms that underlie antimicrobial action of plant-derived compounds. Phytochemicals can act by disrupting microbial membranes (carvacrol, thymol, eugenol, etc.) or impairing cellular metabolism (cinnamaldehyde). They can also control biofilm formation (trans-cinnamaldehyde, carvacrol, thymol, geraniol, etc.). Plant antimicrobials can inhibit bacterial capsule production (salicylic acid and its derivatives). Some plant compounds can attenuate bacterial virulence by controlling quorum-sensing. Another mechanism of plant metabolites' antimicrobial action is the reduction of microbial toxin production (dihydroisosteviol, RG-tannin, etc.) [4, 6]. Plant metabolites can also act as resistance-modifying agents (RMAs). Nowadays RMAs are considered as one of the most prospective ways to combat bacterial resistance. Some studies already showed that plant-derived compounds can enhance therapeutic effect of antibiotics acting as RMAs (nerolidol, bisabolol, apritone, etc.) [2, 6].

Plant species are estimated to be around 250-500 thousands [3]. However, only a small part of them were investigated for antimicrobial activity $[4,10,11]$. People started to use plant materials to treat infectious diseases since ancient times even without any knowledge on their causative agents [12]. Nowadays, herbs continue to be used in traditional medicine to heal various infectious conditions in many countries, including Armenia. Moreover, in the last decades this tendency has increased [13].

Despite relatively small area, Armenia has large diversity of flora with many endemic species. This diversity is mainly due to well-defined vertical zonation, which provides the variety of weather conditions in the country. Since ancient times Armenia has been well-known for its herbal medicine. At the present time the production of herbal teas, essential oils, and powders is well established [14]. There were some studies which tried to evaluate antimicrobial properties of plants from Armenian region. Nevertheless, they were mainly focused on particular plant species or genera. There is lack of massive studies to evaluate medicinal plants of the region for their antimicrobial properties.

Three main approaches can be used to select plants for antimicrobial testing. First approach is to find antimicrobial activity in plants used in folk medicine. The second one is to search antimicrobial properties within plants typical for a particular region or country. And the third approach is to explore antimicrobial efficiency of various plants against a particular microbe [12]. We merged the first two approaches in order to enhance the possibility of finding plants with high antimicrobial efficiency in Armenia.

Our goal was to investigate antimicrobial activity of crude aqueous, methanol, chloroform, acetone, and hexane extracts of five Armenian herbs.

\section{Methods}

Collection, identification and drying of plant materials

Plants species have been chosen based on their use in folk medicine. Particularly, we selected plants which have been used for the treatment of purulent wounds, burns, infections and inflammations. In addition, attention was given to plants typical for Armenian region. The collection of plant materials was done in dry and sunny days. Leaves, flowers and whole plants were harvested in the flowering period. Whereas, fruits, seeds and roots were harvested after maturation according to recommendations [15].

Identification of plant materials was done at the Department of Botany and Mycology, Yerevan State University (Armenia), by Dr. N. Zakaryan and Dr. A. Poghosyan. Immediately after harvesting of plant materials, they were thoroughly washed with distilled water. Then they were placed in drying room under shadow provided with dry air conditioning for ten days. Afterwards, the dried plant materials were fine grounded with a homogenizer (Homogenizer type MPW-302, Poland) and stored in hermetically sealed glass jars at room temperature.

\section{Collected plant materials}

Collected plant materials and details are listed in Additional file 1: Table S1. Voucher specimens of all plants were deposited to the Herbarium of Yerevan State University (Yerevan, Armenia) where serial numbers were given; Agrimonia eupatoria L. (ERCB 13207), Hypericum alpestre subsp. polygonifolium (Rupr.) Avet. \& Takht. (ERCB 13206), Lilium armenum (Miscz. ex Grossh.) Manden. (ERCB 13209), Rumex obtusifolius L. (ERCB 13208), Sanguisorba officinalis L. (ERCB 13205) (See Table 1).

\section{Preparation of plant crude extracts}

Plant materials were extracted by maceration technique with five solvents as follows: distilled water, methanol (98\%), chloroform (99\%), acetone (99.8\%), and hexane (97\%) (Sigma-Aldrich). Grinded plant materials were soaked with each solvent separately at 10:1 solvent-tosample ratio $(\mathrm{v} / \mathrm{w})$. The mixture was thoroughly vortexed for one minute and left in refrigerator at $5^{\circ} \mathrm{C}$ for $24 \mathrm{~h}$ according to the method developed by Rojas et al. 
Table 1 The list of the tested plant species names with common names, family names, tested parts and traditional uses in Armenian folk medicine

\begin{tabular}{|c|c|c|c|c|}
\hline Plant name ${ }^{a}$ & Common name & Family & Part tested & Traditional uses ${ }^{\mathrm{b}}$ \\
\hline Agrimonia eupatoria L. (ERCB 13207) ${ }^{c}$ & $\begin{array}{l}\text { Common } \\
\text { agrimony }\end{array}$ & Rosaceae & Whole plant & $\begin{array}{l}\text { Hepatitis, nephritis, stomatitis, yellow fever, } \\
\text { purulent wounds }\end{array}$ \\
\hline $\begin{array}{l}\text { Hypericum alpestre subsp. polygonifolium } \\
\text { (Rupr.) Avet. \& Takht. (ERCB 13206) }\end{array}$ & Hypericum & Hypericaceae & Aerial part & $\begin{array}{l}\text { Pneumonia, wounds, hepatitis, cholecystitis } \\
\text { gastrointestinal inflammation, nephritis, skin } \\
\text { diseases }\end{array}$ \\
\hline $\begin{array}{l}\text { Lilium armenum (Miscz. ex Grossh.) } \\
\text { Manden. (ERCB 13209) }\end{array}$ & Unknown & Liliumceae & Leaf with stalk, bulb & $\begin{array}{l}\text { Whooping cough, purulent wounds, burns, } \\
\text { leprosy, fungal diseases, mastitis, cystitis }\end{array}$ \\
\hline Rumex obtusifolius L. (ERCB 13208) & $\begin{array}{l}\text { Broad-leaved } \\
\text { dock }\end{array}$ & Polygonaceae & $\begin{array}{l}\text { Leaf, root, inflorescence } \\
\text { seed }\end{array}$ & $\begin{array}{l}\text { Infectious diseases, skin rash, mucosal } \\
\text { inflammation }\end{array}$ \\
\hline Sanguisorba officinalis L. (ERCB 13205) & Great burnet & Rosaceae & Aerial part, root & $\begin{array}{l}\text { Tonsillitis, purulent wounds, inflammations, } \\
\text { skin infections, dysentery, typhoid fever, } \\
\text { trichomoniasis, stomatitis, gingivitis, flu }\end{array}$ \\
\hline
\end{tabular}

${ }^{a}$ The plants names have been checked with http://www.theplantlist.org/

${ }^{\mathrm{b}}$ In this section there are presented only such traditional uses which can imply the presence of antimicrobial compounds [20, 21]

Voucher specimen serial number

[13]. Then, the mixtures were filtered through Whatman filter paper $(11 \mu \mathrm{m}$ pore size). The filtrates were placed in a vacuum chamber (BOV-50 V vacuum drying oven, Biobase Meihua Trading, China) at $40^{\circ} \mathrm{C}$ temperature for drying. Further, fresh solvents were added to the residue at the same ratio and left at $5^{\circ} \mathrm{C}$ for next $24 \mathrm{~h}$. This step was repeated three times in order to achieve maximal extraction of active compounds. Dried crude extracts were weighed and kept at $5^{\circ} \mathrm{C}$ till further use (not more than one month).

\section{Used microorganisms and growth conditions}

Following microorganisms were used as test strains: bacteria Escherichia coli VKPM-M17 (Russian National Collection of Industrial Microorganisms, Moscow, Russia), Pseudomonas aeruginosa GRP3 (Soil and Water Research Institute, Iran), Bacillus subtilis WT-A1, isolated from metal polluted soils of Kajaran, Armenia, Salmonella typhimurium MDC 1754 and Staphylococcus aureus MDC 5233 (Microbial Depository Center, Armbiotechnology Scientific and Production Center, Yerevan, Armenia), yeasts Candida albicans WT-174 isolated from infected vaginal microbiota of hospitalized patients, and Candida guilliermondii HP-17 (Department of Botany and Mycology, YSU, Yerevan, Armenia).

Mueller-Hinton broth medium (MHB) and MuellerHinton agar medium (MHA) (Liofilchem, Italy) were used for cultivation of bacteria. Mueller-Hinton (Broth) Agar $+2 \%$ Glucose medium and $0.5 \mu \mathrm{g} \mathrm{ml}^{-1}$ Methylene Blue Dye (GMB) were used for cultivation of yeasts [16].

\section{Preparation of stock solutions}

The stock solutions of the samples were prepared by dissolving crude dried extracts in pure dimethyl sulfoxide (DMSO) (Sigma-Aldrich) (in order to avoid sterile filtration), with the exception of aqueous extracts, which were dissolved in sterile distilled water and filtered through $0.22 \mu \mathrm{m}$ sterile filter (Millipore).

\section{Initial evaluation of plants' antibacterial and anti-yeast activity}

The antimicrobial activity of the samples were initially evaluated by modified agar well diffusion assay [17]. Growth medium $(25 \mathrm{ml})$ was poured into Petri dishes at $50-70{ }^{\circ} \mathrm{C}$ and it was left to solidify under ultraviolet (UV) light (265 $\mathrm{nm}$ wavelength) for $15 \mathrm{~min}$. Subsequently, a sterile cotton swab was dipped into overnight bacterial or yeast suspensions of indicator strains (adjusted to turbidity of 0.5 McFarland Standard). An agar plate was inoculated by evenly streaking cotton swab over the agar medium. Then wells with a diameter of $8 \mathrm{~mm}$ were cut in the medium with a sterile cork borer. Stock solutions of the samples were diluted in sterile distilled water to get $500 \mu \mathrm{g} \mathrm{ml}{ }^{-1}$ concentrations. The tested samples and controls $(100 \mu \mathrm{l})$ were dispensed into the wells. The plates were incubated at $37{ }^{\circ} \mathrm{C}$ for $24 \mathrm{~h}$. Then the diameters of growth inhibition zones around the wells were measured. Following control agents were used: positive control agents - gentamicin $\left(10 \mu \mathrm{g} \mathrm{ml}^{-1}\right)$ (for bacteria) and nystatin $20 \mu \mathrm{g} \mathrm{ml}^{-1}$ (for yeasts); negative control agent - 5\% DMSO.

\section{Determination of MIC values}

Determination of Minimum inhibitory concentrations (MIC) of plant crude extracts was done using broth microdilution method [18]. Sample concentration range was prepared from the stock solutions by two-fold dilutions in sterile broth. Six dilutions of the samples ranging from 32 to $1024 \mu \mathrm{g} \mathrm{m}{ }^{-1}$ were tested. The inoculums of test strains prepared from fresh overnight cultures were adjusted to 0.5 McFarland standard, which equals to $1-2 \times 10^{8} \mathrm{CFU} \mathrm{ml}{ }^{-1}$ for bacteria and 1-5 $\times 10^{6}$ 
CFU $\mathrm{ml}^{-1}$ for yeasts. The inoculums then were diluted in 1:100 ratio in case of bacteria and in 1:10 ratio for yeasts in order to get $1-5 \times 10^{5} \mathrm{CFU} \mathrm{ml} \mathrm{m}^{-1}$ concentrations. The $75 \mu \mathrm{l}$ volume of samples were poured to each well of 96-well microplate (Sarstedt, Germany). Then $75 \mu \mathrm{l}$ volume of test strain suspensions were added to them. The highest dilution of samples without visible growth after $24 \mathrm{~h}$ incubation at $37^{\circ} \mathrm{C}$ was considered as MIC.

For this assay the positive control agents were gentamicin (range: $0.03-2 \mu \mathrm{g} \mathrm{ml}^{-1}$ ) for bacteria and nystatin (range: $0.06-4 \mu \mathrm{g} \mathrm{ml}^{-1}$ ) for yeasts. Whereas, $1 \%$ DMSO (which was present in extracts with $1024 \mu \mathrm{g} \mathrm{ml}{ }^{-1}$ concentration) and broth were used as negative controls. All dilutions of crude extracts were cultured in agar media for sterility test.

\section{Determination of $\mathrm{MBC} / \mathrm{MFC}$ values}

Minimum bactericidal/fungicidal concentrations (MBC/ MFC) of the plant crude extracts were determined by sub-culturing the samples $(5 \mu \mathrm{l})$ taken from the wells without growth during MIC determination on agar medium. The lowest concentration of crude extracts with the absence of growth after $24 \mathrm{~h}$ incubation at 37 ${ }^{0} \mathrm{C}$ was considered as $\mathrm{MBC} / \mathrm{MFC}$.

\section{Data processing}

All experiments were independently repeated three times. Obtained data were processed; standard deviations were calculated using GraphPad Prism 5.03 (GraphPad Software, Inc.; USA) software.

\section{Results and dicussion}

\section{Screening of plant materials and selection of the most} prospective plants

Five plant species: Sanguisorba officinalis, Rumex obtusifolius, Hypericum alpestre, Lilium armenum and Agrimonia eupatoria (Additional file 1: Table S1), were chosen based on initial in vitro evaluation of antimicrobial activities of different parts of 28 wild plant species against five bacterial and two yeast strains. All plant materials are widely used in Armenian traditional medicine.

In order to select the most active parts of five plant species, agar well diffusion assay was used. We used $500 \mu \mathrm{g} \mathrm{ml}^{-1}$ concentration of crude extracts $(50 \mu \mathrm{g}$ dry material for each well) for agar well diffusion assay according to recommendations [12, 19]. Rios and Recio (2005) in their review stated that using crude extracts of plant materials with concentrations above $1000 \mu \mathrm{g} \mathrm{ml}^{-1}$ in antimicrobial screening protocols should be avoided, because using high concentrations of plant crude extracts can bring to false positive results [19].

According to the obtained data all plant parts possessed antimicrobial activity against at least three tested strains (see Table 2). In order to select prospective plant parts for further comprehensive studies we used two main criteria. At first, we paid attention to plant extracts with the highest growth inhibition zones. We also gave a priority toward the samples which had broad spectrum of action against various microbial groups (Gram-positive, Gram-negative, endospore forming bacteria and yeast). Thus, according to data obtained (see Table 2) following plant parts were chosen for further more profound investigation: Sanguisorba officinalis (aerial part), Rumex obtusifolius (seed), Hypericum alpestre (aerial part), Lilium armenum (bulb), and Agrimonia eupatoria (whole plant).

All tested parts of Rumex obtusifolius demonstrated substantial antimicrobial activity with some differences (see Table 2). For example, only root extracts exhibited antimicrobial activity against $C$. albicans. In turn they did not inhibit the growth of $E$. coli, whereas its other parts did. B. subtilis was more sensitive to crude extracts of inflorescence and seed of Rumex obtusifolius. In contrast, tested yeast strains were more sensitive to leaf and root extracts of this plant. Acetone and methanol extract of Rumex obtusifolius seeds showed the highest antimicrobial activity against all tested strains except $C$. albicans. Consequently, we have chosen this part for further study. Other parts of Rumex obtusifolius had less efficiency compared to the seeds. Although root crude extracts had lower activity than seed extracts, however, they were also interesting due to their activity against $C$. albicans.

Aerial part of Lilium armenum inhibited the growth of only three bacterial test strains. Meanwhile, its bulb extracts exhibited activity against all tested bacterial strains. Moreover, growth inhibition zones of the bulb extracts exceed zones, induced by the aerial part. Therefore, the bulb part of Lilium armenum was chosen for further studies. This plant is also considered interesting, as it is native to Armenia, where it is widely used in folk medicine. However, to this date there have been no studies about its antimicrobial properties [20, 21].

Among all the tested plant materials the largest zones of inhibition were induced by Hypericum alpestre extracts (see Table 2). They exhibited activity against almost all test strains with the exception of $C$. albicans and S. typhimurium. Even though other species of the genera Hypericaceae were widely investigated and their high antimicrobial activity has already been shown in the literature [22, 23], there was no information about Hypericum alpestre's antimicrobial properties. However, it was the most commonly used species in traditional medicine within the genera in the region from where it was collected.

Even though the use of the roots of Sanguisorba officinalis is more common in traditional medicine [20, 21], the obtained data demonstrated higher antimicrobial 
Table 2 Antibacterial and anti-yeast activity of the tested plant extracts determined by agar well diffusion assay

\begin{tabular}{|c|c|c|c|c|c|c|c|c|c|}
\hline \multirow[t]{2}{*}{ Plant species } & \multirow[t]{2}{*}{ Part tested } & \multirow[t]{2}{*}{ Extract } & \multicolumn{7}{|c|}{ Diameter of growth inhibition zone with standard deviation (mm) } \\
\hline & & & $S A^{a}$ & $B S$ & $P A$ & $E C$ & ST & $C G$ & $C A$ \\
\hline \multirow[t]{5}{*}{ Agrimonia eupatoria } & \multirow[t]{5}{*}{ Whole plant } & Water & - & - & - & $9 \pm 0.6$ & - & - & - \\
\hline & & Methanol & $10 \pm 0.6$ & $11 \pm 0.6$ & $11 \pm 0.6$ & $11 \pm 0.6$ & - & $11 \pm 0.6$ & - \\
\hline & & Chloroform & 9 & $11 \pm 0.6$ & $10 \pm 0.6$ & $10 \pm 0.6$ & $11 \pm 0.6$ & $12 \pm 0.6$ & $9 \pm 0.6$ \\
\hline & & Acetone & $12 \pm 0.6$ & $10 \pm 0.6$ & $11 \pm 0.6$ & $10 \pm 0.6$ & $10 \pm 0.6$ & $12 \pm 1$ & $9 \pm 0.6$ \\
\hline & & Hexane & $13 \pm 0.6$ & $10 \pm 0.6$ & $10 \pm 0.6$ & - & $9 \pm 0.6$ & $9 \pm 0.6$ & - \\
\hline \multirow[t]{5}{*}{ Hypericum alpestre } & \multirow[t]{5}{*}{ Aerial part } & Water & - & - & $11 \pm 0.6$ & - & - & - & - \\
\hline & & Methanol & $10 \pm 0.6$ & $11 \pm 0.6$ & $18 \pm 0.6$ & $10 \pm 0.6$ & - & - & - \\
\hline & & Chloroform & $13 \pm 0.6$ & $12 \pm 0.6$ & $23 \pm 1$ & - & - & - & - \\
\hline & & Acetone & $15 \pm 0.6$ & $13 \pm 0.6$ & $21 \pm 0.6$ & - & $10 \pm 0.6$ & $9 \pm 0.6$ & - \\
\hline & & Hexane & $17 \pm 0.6$ & $16 \pm 0.6$ & $21 \pm 0.6$ & - & - & - & - \\
\hline \multirow[t]{5}{*}{ Lilium armenum } & \multirow[t]{5}{*}{ Stalk with leaf } & Water & - & - & $10 \pm 0.6$ & - & - & - & - \\
\hline & & Methanol & $9 \pm 0.6$ & - & $13 \pm 0.6$ & - & - & - & - \\
\hline & & Chloroform & $9 \pm 0.6$ & - & $10 \pm 0.6$ & - & - & - & - \\
\hline & & Acetone & $10 \pm 0.6$ & 9 & $11 \pm 0.6$ & - & - & - & - \\
\hline & & Hexane & $9 \pm 0.6$ & - & $12 \pm 0.6$ & - & - & - & - \\
\hline \multirow[t]{5}{*}{ Lilium armenum } & \multirow[t]{5}{*}{ Bulb } & Water & - & - & $9 \pm 0.6$ & - & - & - & - \\
\hline & & Methanol & $9 \pm 0.6$ & $9 \pm 0.6$ & $11 \pm 0.6$ & $9 \pm 0.6$ & - & - & - \\
\hline & & Chloroform & $9 \pm 0.6$ & - & $13 \pm 0.6$ & - & $9 \pm 0.6$ & - & - \\
\hline & & Acetone & $10 \pm 0.6$ & $9 \pm 0.6$ & $11 \pm 0.6$ & $9 \pm 0.6$ & $9 \pm 0.6$ & - & - \\
\hline & & Hexane & - & - & $11 \pm 0.6$ & - & $9 \pm 0.6$ & - & - \\
\hline \multirow[t]{5}{*}{ Rumex obtusifolius } & \multirow[t]{5}{*}{ Leaf } & Water & - & - & - & - & - & - & - \\
\hline & & Methanol & $9 \pm 0.6$ & - & - & - & $10 \pm 0.6$ & $14 \pm 0.6$ & - \\
\hline & & Chloroform & $11 \pm 0.6$ & - & $10 \pm 0.6$ & - & $10 \pm 0.6$ & $9 \pm 0.6$ & - \\
\hline & & Acetone & $11 \pm 0.6$ & - & $12 \pm 0.6$ & - & $10 \pm 0.6$ & $12 \pm 0.6$ & - \\
\hline & & Hexane & $9 \pm 0.6$ & - & $11 \pm 0.6$ & $9 \pm 0.6$ & - & - & - \\
\hline \multirow[t]{5}{*}{ Rumex obtusifolius } & \multirow[t]{5}{*}{ Root } & Water & - & - & $11 \pm 0.6$ & - & - & - & - \\
\hline & & Methanol & $10 \pm 0.6$ & - & $10 \pm 0.6$ & - & - & - & $9 \pm 0.6$ \\
\hline & & Chloroform & $11 \pm 0.6$ & - & $10 \pm 0.6$ & - & $9 \pm 0.6$ & $12 \pm 0.6$ & $9 \pm 0.6$ \\
\hline & & Acetone & $10 \pm 0.6$ & $9 \pm 0.6$ & $12 \pm 0.6$ & - & - & $13 \pm 0.6$ & $9 \pm 0.6$ \\
\hline & & Hexane & $9 \pm 0.6$ & - & - & - & - & $12 \pm 0.6$ & - \\
\hline \multirow[t]{5}{*}{ Rumex obtusifolius } & \multirow[t]{5}{*}{ Inflorescence } & Water & - & - & - & - & - & - & - \\
\hline & & Methanol & - & $9 \pm 0.6$ & $9 \pm 0.6$ & $10 \pm 0.6$ & - & - & - \\
\hline & & Chloroform & - & $9 \pm 0.6$ & $9 \pm 0.6$ & $9 \pm 0.6$ & - & - & - \\
\hline & & Acetone & $11 \pm 0.6$ & $11 \pm 0.6$ & $9 \pm 0.6$ & $10 \pm 0.6$ & $9 \pm 0.6$ & $9 \pm 0.6$ & - \\
\hline & & Hexane & $9 \pm 0.6$ & $9 \pm 0.6$ & $10 \pm 0.6$ & - & - & - & - \\
\hline \multirow[t]{5}{*}{ Rumex obtusifolius } & \multirow[t]{5}{*}{ Seed } & Water & $9 \pm 0.6$ & - & $10 \pm 0.6$ & - & - & - & - \\
\hline & & Methanol & $12 \pm 0.6$ & $11 \pm 0.6$ & $10 \pm 0.6$ & $11 \pm 0.6$ & $12 \pm 0.6$ & $10 \pm 0.6$ & - \\
\hline & & Chloroform & - & $9 \pm 0.6$ & $9 \pm 0.6$ & - & - & - & - \\
\hline & & Acetone & $12 \pm 0.6$ & $12 \pm 0.6$ & $10 \pm 0.6$ & $10 \pm 0.6$ & $12 \pm 0.6$ & $10 \pm 0.6$ & - \\
\hline & & Hexane & $9 \pm 0.6$ & $9 \pm 0.6$ & $10 \pm 0.6$ & - & - & - & - \\
\hline \multirow[t]{3}{*}{ Sanguisorba obtusifolius } & \multirow[t]{3}{*}{ Aerial part } & Water & - & - & $10 \pm 0.6$ & - & $9 \pm 0.6$ & - & - \\
\hline & & Methanol & $12 \pm 0.6$ & $11 \pm 0.6$ & $10 \pm 0.6$ & $10 \pm 0.6$ & $12 \pm 0.6$ & $9 \pm 0.6$ & $10 \pm 0.6$ \\
\hline & & Chloroform & $10 \pm 0.6$ & $9 \pm 0.6$ & $10 \pm 0.6$ & - & - & $12 \pm 0.6$ & $11 \pm 0.6$ \\
\hline
\end{tabular}


Table 2 Antibacterial and anti-yeast activity of the tested plant extracts determined by agar well diffusion assay (Continued)

\begin{tabular}{|c|c|c|c|c|c|c|c|c|c|}
\hline & & Acetone & $13 \pm 0.6$ & $13 \pm 0.6$ & $12 \pm 1$ & $12 \pm 0.6$ & $11 \pm 0.6$ & $10 \pm 0.6$ & $10 \pm 0.6$ \\
\hline & & Hexane & $11 \pm 0.6$ & $10 \pm 0.6$ & $10 \pm 0.6$ & $9 \pm 0.6$ & - & $10 \pm 0.6$ & $9 \pm 0.6$ \\
\hline \multirow[t]{6}{*}{ Sanguisorba officinalis } & Root & Water & - & - & - & - & - & - & - \\
\hline & & Methanol & $10 \pm 0.6$ & - & $10 \pm 0.6$ & $10 \pm 0.6$ & - & $10 \pm 0.6$ & $10 \pm 0.6$ \\
\hline & & Chloroform & - & - & - & - & - & $10 \pm 0.6$ & $11 \pm 0.6$ \\
\hline & & Acetone & $10 \pm 0.6$ & $10 \pm 0.6$ & $10 \pm 0.6$ & $10 \pm 0.6$ & - & $10 \pm 0.6$ & $10 \pm 0.6$ \\
\hline & & Hexane & - & - & - & - & - & - & $10 \pm 0.6$ \\
\hline & $P C^{b}$ & & $20 \pm 0.6$ & $30 \pm 1$ & $28 \pm 1$ & $19 \pm 0.6$ & $23 \pm 0.6$ & $24 \pm 0.6$ & $23 \pm 0.6$ \\
\hline
\end{tabular}

${ }^{a}$ Used test strains: Escherichia coli WKPM-M17 (EC), Pseudomonas aeruginosa GRP3 (VKPH B-82-5) (PA), Bacillus subtilis WT-A1 (BS), Salmonella typhimurium WDCM 1754 (ST), Staphylococcus aureus WDCM 5233 (SA), Candida albicans 174 (CA), Candida guilliermondii HP-17 (CG)

${ }^{\mathrm{b}} \mathrm{PC}$ - positive control (gentamicin $\left(10 \mu \mathrm{g} \mathrm{ml}^{-1}\right.$ ) (for bacteria), nystatin $20 \mu \mathrm{g} \mathrm{ml} \mathrm{m}^{-1}$ (for yeasts))

All experiments were independently repeated three times. Average means with standard deviations are represented. Standard deviations were calculated with

GraphPad Prism 5.03 (GraphPad Software, Inc.; USA) software

activity of the aerial part compared to the root. Acetone and methanol extracts of Sanguisorba officinalis's aerial part inhibited the growth of the tested strains whereas crude extracts of the root did not show activity against S. typhimurium at tested concentrations. Therefore, we selected the aerial part for further research. Crude extracts of Agrimonia eupatoria also inhibited the growth of all tested bacterial and yeast strains (see Table 2). Although Sanguisorba officinalis and Agrimonia eupatoria were already investigated in many research works and their high antimicrobial activity was shown [24-26], it was interesting to study these plants in order to find out any possible differences between the activity of same plant species from various geographical areas.

We compared the activities of the tested plant materials against Gram-negative and Gram-positive bacteria based on agar well diffusion assay (Additional file 1: Table S2). Crude extracts of Hypericum alpestre were more active against Gram-positive bacteria. In case of Rumex obtusifolius, Lilium armenum, Agrimonia eupatoria and Sanguisorba officinalis in general similar activity was observed against both Gram-negative and Grampositive bacteria.

Thus, screening of different parts of plant species used in Armenian folk medicine allowed us to evaluate their antimicrobial properties at $500 \mu \mathrm{g} \mathrm{ml}{ }^{-1}$ concentration and choose the most active plant parts for further studies. On the other hand, the obtained results enabled the evaluation of comparative effectiveness of five different solvents for their ability to solubilize antimicrobial compounds from plant materials.

\section{Determination of MIC values of selected plant materials}

MIC values of the selected five plant parts: Lilium armenum (bulb), Rumex obtusifolius (seed), Hypericum alpestre (aerial part), Agrimonia eupatoria (whole plant) and Sanguisorba officinalis (aerial part) extracted with five solvents were determined (see Table 3). According to collected data MIC values of the tested extracts generally varied within the range from $64 \mu \mathrm{g} \mathrm{ml} \mathrm{m}^{-1}$ to $1024 \mu \mathrm{g} \mathrm{ml}$ ${ }^{-1}$. The MIC values of aqueous, chloroform and hexane extracts for almost all tested plants were relatively high. Therefore, they cannot be considered for any further practical use based on their weak activity. The exceptions were chloroform and hexane extracts of Hypericum alpestre which had low $\left(128 \mu \mathrm{g} \mathrm{ml}^{-1}\right) \mathrm{MIC}$ values against S. aureus. Moreover, hexane extract of this plant continued to be active till $64 \mu \mathrm{g} \mathrm{ml}^{-1}$ concentration against $P$. aeruginosa. Another exception was hexane extract of Agrimonia eupatoria with $128 \mu \mathrm{g} \mathrm{ml}^{-1} \mathrm{MIC}$ value against $P$. aeruginosa. In contrast, MICs of acetone and methanol extracts of the tested plant materials had fairly low values against some test strains. For instance, methanol and acetone extracts of Hypericum alpestre had $128 \mu \mathrm{g} \mathrm{ml}^{-1}$ and $64 \mu \mathrm{g} \mathrm{ml}^{-1}$ MIC values respectively against $P$. aeruginosa. The MIC of acetone extract of the same plant against $S$. aureus and B. subtilis was $128 \mu \mathrm{g} \mathrm{ml}^{-1}$. The MIC value of acetone extract of Sanguisorba officinalis against $P$. aeruginosa was $64 \mu \mathrm{g} \mathrm{ml}^{-1}$. Acetone and methanol extracts of Rumex obtusifolius had $128 \mu \mathrm{g} \mathrm{ml}^{-1}$ MIC value against B. subtilis and $P$. aeruginosa. On the other hand, selected plants' crude extracts possessed broad range of activity inhibiting the growth of Gram-negative, Gram-positive and endospore forming bacteria. They also showed considerable activity against yeasts. Among the tested five plants Agrimonia eupatoria, Rumex obtusifolius and Sanguisorba officinalis had lower MIC values against yeast strains, compared to Hypericum alpestre and Lilium armenum, which in contrast, inhibited the growth of yeast strains only in high concentrations.

Comparison of obtained MIC values of the tested plant materials with literature data showed both similaraities and differences. Wegiera et al. [27] showed that ethanol extracts of Rumex confertus seeds had $62.5-125 \mu \mathrm{g} \mathrm{ml}{ }^{-1}$ MIC values against $S$. aureus strains which is in coincidence with our data. The results were also similar in case of E. coli. However, in case of $P$. aeruginosa and $C$. 
Table 3 Determination of minimum inhibitory concentration (MIC) and Minimum bactericidal/fungicidal concentrations (MBC/MFC) of crude extracts of five selected plant materials. (Place in the text: page 10 after line 13)

\begin{tabular}{|c|c|c|c|c|c|c|c|c|c|c|c|c|c|c|c|}
\hline \multirow[t]{3}{*}{ Plant species } & \multirow[t]{3}{*}{ Extract $^{\mathrm{a}}$} & \multicolumn{14}{|c|}{ 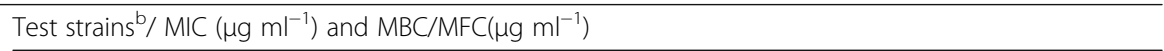 } \\
\hline & & \multicolumn{2}{|l|}{$S A$} & \multicolumn{2}{|l|}{$B S$} & \multicolumn{2}{|l|}{$P A$} & \multicolumn{2}{|l|}{$E C$} & \multicolumn{2}{|l|}{ ST } & \multicolumn{2}{|l|}{ CG } & \multicolumn{2}{|l|}{$C A$} \\
\hline & & $\mathrm{MIC}$ & $\mathrm{MBC}$ & $\mathrm{MIC}$ & $\mathrm{MBC}$ & $\mathrm{MIC}$ & $\mathrm{MBC}$ & $\mathrm{MIC}$ & $\mathrm{MBC}$ & $\mathrm{MIC}$ & $\mathrm{MBC}$ & $\mathrm{MIC}$ & $\mathrm{MBC}$ & $\mathrm{MIC}$ & $\mathrm{MBC}$ \\
\hline \multirow[t]{5}{*}{ Hypericum alpestre (aerial part) } & Wat & 1024 & - & - & - & 256 & - & - & - & 1024 & & - & - & - & - \\
\hline & Met & 256 & 512 & 256 & 512 & 128 & 1024 & 512 & - & - & - & - & - & - & - \\
\hline & CF & 128 & - & 256 & 1024 & 256 & 1024 & 1024 & - & 1024 & - & 1024 & - & - & - \\
\hline & Ace & 128 & - & 128 & 512 & 64 & 512 & 1024 & - & 512 & - & 1024 & - & 1024 & - \\
\hline & Hex & 128 & 512 & 256 & 512 & 64 & 512 & 1024 & - & 1024 & - & 1024 & - & - & - \\
\hline \multirow[t]{5}{*}{ Agrimonia eupatoria (whole plant) } & Wat & 1024 & - & - & - & 1024 & - & 1024 & - & 1024 & - & 1024 & - & - & - \\
\hline & Met & 256 & - & 128 & - & 256 & 1024 & 512 & - & 1024 & - & 1024 & - & - & - \\
\hline & CF & 256 & 512 & 256 & 1024 & 512 & 1024 & 512 & - & 512 & - & 256 & 1024 & 512 & - \\
\hline & Ace & 256 & - & 128 & 1024 & 128 & 512 & 512 & - & 512 & - & 256 & - & 512 & - \\
\hline & Hex & 256 & 1024 & 256 & 1024 & 128 & 512 & - & - & 512 & - & 512 & 1024 & 1024 & - \\
\hline \multirow[t]{5}{*}{ Lilium armenum (bulb) } & Wat & 1024 & - & 1024 & - & 1024 & - & - & - & 1024 & - & - & - & - & - \\
\hline & Met & 512 & - & 512 & 1024 & 256 & 512 & 1024 & - & - & - & 1024 & - & - & - \\
\hline & CF & 512 & - & 1024 & - & 128 & 512 & 1024 & - & 512 & - & 512 & 1024 & 1024 & - \\
\hline & Ace & 512 & - & 512 & - & 128 & 512 & 512 & - & 512 & - & - & - & - & - \\
\hline & Hex & 1024 & - & 1024 & - & 256 & - & - & - & 1024 & - & - & - & - & - \\
\hline \multirow[t]{5}{*}{ Rumex obtusifolius (seed) } & Wat & 512 & - & 1024 & - & 256 & 1024 & - & - & 1024 & & 1024 & - & 1024 & - \\
\hline & Met & 256 & - & 128 & - & 128 & 512 & 512 & - & 512 & & 512 & - & - & - \\
\hline & CF & 1024 & - & 1024 & - & 512 & - & - & - & 1024 & - & 1024 & - & - & - \\
\hline & Ace & 256 & - & 128 & - & 128 & 1024 & 512 & - & 512 & & 512 & - & - & - \\
\hline & Hex & 512 & - & 512 & - & 512 & 1024 & - & - & 1024 & - & 1024 & - & 1024 & - \\
\hline \multirow[t]{6}{*}{ Sanguisorba officinalis (aerial part) } & Wat & - & - & 1024 & - & 512 & - & - & - & - & - & - & - & - & - \\
\hline & Met & 256 & - & 128 & 512 & 256 & 512 & 512 & - & 512 & - & 512 & - & 512 & - \\
\hline & CF & 512 & - & 512 & - & 128 & 256 & 1024 & & 1024 & & 512 & 1024 & 512 & \\
\hline & Ace & 128 & - & 128 & 1024 & 64 & 256 & 256 & - & 256 & - & 512 & - & 512 & - \\
\hline & Hex & 256 & - & 512 & 1024 & 256 & 512 & 1024 & - & 1024 & - & 256 & - & 512 & - \\
\hline & $P C^{d}$ & 0.25 & 0.5 & 0.25 & 0.5 & 0.25 & 0.5 & 0.5 & 2 & 1 & $>2$ & 2 & $>4$ & 2 & 4 \\
\hline
\end{tabular}

axtracts: Wat- Water, Met -Methanol, CF-Chloroform, Ace- Acetone, Hex - Hexane

b Test strains: Escherichia coli WKPM-M17 (EC), Pseudomonas aeruginosa GRP3 (VKPH B-82-5) (PA), Bacillus subtilis WT-A1 (BS), Salmonella typhimurium WDCM 1754 (ST), Staphylococcus aureus WDCM 5233 (SA), Candida albicans 174 (CA), Candida guilliermondii HP-17 (CG)

${ }^{c}(-)$ : MIC/MBC/MFC value was $>1024 \mu \mathrm{g} \mathrm{ml}^{-1}$

${ }^{d}$ PC: positive control (gentamicin (range 2-0.003 $\mathrm{g} \mathrm{m} \mathrm{ml}^{-1}$ ) (for bacteria), nystatin (range 4-0.125 $\mu \mathrm{g} \mathrm{ml}{ }^{-1}$ ) (for yeasts))

All experiments were repeated three times and average means were represented

albicans the MIC values obtained by Wegiera et al. [27] were different from our results. In our experiments methanol and acetone extracts of Rumex obtusifolius had $128 \mu \mathrm{g} \mathrm{ml}^{-1}$ MIC value against $P$. aeruginosa, whereas its MIC was above the $500 \mu \mathrm{g} \mathrm{ml}^{-1}$ in the other research [27]. The MIC against $C$. albicans were above $1024 \mu \mathrm{g} \mathrm{ml}^{-1}$ in our experiments. In contrast, it was $250 \mu \mathrm{g} \mathrm{ml}^{-1}$ in research done by Wegiera et al. [27]. These differences could be explained by differential susceptibility of the used test strains. Copland et al. [28] in their research showed that only hexane extracts of Agrimonia eupatoria seeds (they tested methanol and dichloromethane extracts as well) showed activity against $B$. subtilis with $750 \mu \mathrm{g} \mathrm{ml}^{-1}$ MIC value at tested concentrations. They did not find antimicrobial activity against tested $P$. aeruginosa and $S$. aureus strains. In contrast, Watkins et al. [29] who used water, red wine, as well as $25 \%$ and $75 \%$ ethanol as solvents, showed that Agrimonia eupatoria had moderate antimicrobial activity against S. aureus, B. subtilis and E. coli. Antimicrobial activity of ethanol extract of Agrimonia eupatoria against Helicobacter pylori was also shown [30]. Kokoska et al. [25] showed that ethanol extracts of Sanguisorba officinalis had $62.5-250 \mu \mathrm{g} \mathrm{ml}^{-1}$ MIC values against $E$. coli, S. aureus and P. aeruginosa which partially coincides with our data. There was no evidence in literature 
about antimicrobial activity of Lilium armenum and $\mathrm{Hy}$ pericum alpestre.

\section{Determination of MBC/MFC values of the selected plant materials}

$\mathrm{MBC} / \mathrm{MFC}$ of selected five plant materials was determined. Three of the tested five plant species Agrimonia eupatoria, Sanguisorba officinalis and Lilium armenum possessed fungicidal activity against C. guilliermondii (see Table 3). Only Hypericum alpestre and Agrimonia eupatoria extracts killed $S$. aureus cells. In contrast, all five plant materials expressed bactericidal activity against $P$. aeruginosa: some of them even at $256 \mu \mathrm{g} \mathrm{ml}^{-1}$ concentrations (chloroform and acetone extracts of Sanguisorba officinalis). Within tested five plant species only Rumex obtusifolius had no bactericidal activity against $B$. subtilis at tested concentrations. This is particularly interesting as tested B. subtilis strain could have high resistance according to our previous work [17]. Cidal activity of almost all tested plant materials toward this endospore forming bacteria also allowed us to assume that they possessed activity against endospores as well. All tested plant materials showed only static activity against E. coli, S. typhimurium and C. albicans till the concentration of $1024 \mu \mathrm{g} \mathrm{ml}{ }^{-1}$. The obtained data indicated that MBC/MFC concentrations were two-three times higher than respective MIC values.

We did not find any research about bactericidal/fungicidal activity of all tested five plant species. Therefore, bactericidal/fungicidal activity of these plants was investigated for the first time.

\section{Evaluation of tested solvents' efficiency}

Since we used five solvents in our screening protocol, the collected data allowed us to evaluate solvents for their efficiency to solubilize antimicrobial compounds from plant materials as well as their other properties. The obtained results (see Tables 2 and 3) showed that acetone extracts demonstrated the highest antimicrobial activities for almost all tested plant materials. Methanol extracts showed the second strongest antimicrobial activity, followed by chloroform, hexane and water. Methanol was the best solvent in regard of quantity of extracted materials, followed by water, acetone, chloroform and hexane. During extraction with hexane, only small amount of dry material was harvested. From the point of easy handling (quick evaporation, easy harvesting and weighing, high further solubility in DMSO, absence of residual moisture) we considered methanol as the best solvent, followed by acetone, water, chloroform and hexane. Our considerations about solvent efficiency agree with literature data. According to Eloff [9], acetone received the best overall rating for yielding antimicrobials from plant materials among the tested six common solvents (methylene dichloride, methanol, ethanol, water, acetone, and a mixture of chloroform, methanol and water). However, Eloff [9] conducted his study only on two plant materials, therefore, there was a necessity for more data for generalization of effectiveness of acetone as an extractant. Mothana and Lindequist [31] showed that methanol extracts were more active than chloroform extracts which confirms our data. In our study aqueous extracts have shown poor antimicrobial activities at tested concentrations which coincides with literature data $[3,10,31-33]$.

\section{Conclusions}

Thus, antimicrobial activity of five plant materials was evaluated against five bacterial and two yeast strains. Some of the plants had quite low MIC/MBC and therefore have prospective for further more comprehensive studies. We also established that acetone was the most effective solvent among the tested five solvents for solubilizing antimicrobial compounds from the tested plant materials. Hence, we propose using acetone in antimicrobial screening protocols. In further research we will to try to purify the plants' active compounds responsible for their antimicrobial action. Synergistic effect of these five plants extracts with commonly used antibiotics is also interesting.

\section{Additional file}

Additional file 1: Table S1. The list of initially tested 28 wild plant species with common names, family names, tested parts and traditional uses in Armenian folk medicine. Table S2. Antibacterial and anti-yeast activity of crude extracts of tested 28 wild plant species determined by agar well diffusion assay. (DOCX $47 \mathrm{~kb}$ )

\section{Abbreviations}

Ace: Acetone; BS: Bacillus subtilis; CA: Candida albicans; CF: Chloroform; CG: Candida guilliermondii; EC: Escherichia coli; Hex: Hexane; Met: Methanol; PA: Pseudomonas aeruginosa; PC: Positive control; SA: Staphylococcus aureus; ST: Salmonella typhimurium; Wat: Water.

\section{Acknowledgements}

The authors thank Dr. N. Zakaryan and Dr. A. Poghosyan from Department of Botany and Mycology, Yerevan State University (Armenia), for helping in identification of collected plant materials. We also acknowledge local healers for their recommendations to choose most prospective plants.

\section{Funding}

The study was done in framework of Basic support from State Committee of Science, Ministry of Education and Science of Armenia.

\section{Availability of data and materials}

Not applicable.

\section{Authors' contributions}

MG, MP, AT proposed and designed the study; MG collected plant materials, interviewed with local healers and carried out the experimental part of the manuscript. MG and MP analyzed the generated data. AT helped to draft the manuscript and in critical revision. All authors read and approved the final manuscript. 


\section{Competing interests}

The authors declare that they have no competing interests.

\section{Consent for publication}

Not applicable.

\section{Ethics approval and consent to participate}

Not applicable.

Received: 29 May 2016 Accepted: 11 January 2017

Published online: 17 January 2017

\section{References}

1. World Health Organization. Antimicrobial resistance. Antimicrob Resist Glob Rep surveillance. Geneva: WHO Press; 2014.

2. Abreu AC, McBain AJ, Simões M. Plants as sources of new antimicrobials and resistance-modifying agents. Nat Prod Rep. 2012;29:1007-21. Available from: http://www.ncbi.nlm.nih.gov/pubmed/22786554.

3. Cowan MM. Plant Products as Antimicrobial Agents. Clin Microbiol Rev. 1999;12:564-82. Available from: http://cmr.asm.org/content/12/4/564.short.

4. Savoia D. Plant-derived antimicrobial compounds: alternatives to antibiotics. 2012. p. 979-90.

5. Rajeh MAB, Zuraini Z, Sasidharan S, Latha LY, Amutha S. Assessment of Euphorbia hirta L. leaf, flower, stem and root extracts for their antibacterial and antifungal activity and brine shrimp lethality. Molecules. 2010;15:6008-18.

6. Upadhyay A, Upadhyaya I, Kollanoor-Johny A, Venkitanarayanan K. Combating Pathogenic Microorganisms Using Plant-Derived Antimicrobials: A Minireview of the Mechanistic Basis. Biomed Res Int. 2014;2014:18. https:// www.hindawi.com/journals/bmri/2014/761741.

7. Rates SMK. Plants as source of drugs. Toxicon. 2001;39:603-13.

8. Ahmad I, Beg AZ. Antimicrobial and phytochemical studies on 45 Indian medicinal plants against multi-drug resistant human pathogens. J Ethnopharmacol. 2001;74:113-23.

9. Eloff JN. Which extractant should be used for the screening and isolation of antimicrobial components from plants? J Ethnopharmacol. 1998;60:1-8.

10. Petrosyan M, Shcherbakova Y, Sahakyan N, Vardanyan Z, Poladyan A, Popov $Y$, et al. Alkanna orientalis (L.) Boiss. plant isolated cultures and antimicrobial activity of their extracts: phenomenon, dependence on different factors and effects on some membrane-associated properties of bacteria. Plant Cell Tissue Organ Cult. 2015;122:727-38.

11. Borris RP. Natural products research: perspectives from a major pharmaceutical company. J Ethnopharmacol. 1996;51:29-38.

12. Ríos JL, Recio MC. Medicinal plants and antimicrobial activity. J Ethnopharmacol. 2005;100:80-4

13. Rojas JJ, Ochoa VJ, Ocampo SA, Muñoz JF. Screening for antimicrobial activity of ten medicinal plants used in Colombian folkloric medicine: a possible alternative in the treatment of non-nosocomial infections. BMC Complement Altern Med. 2006;6:2.

14. Tamanyan K, Fayvush G, Nanagyulyan S, Danielyan T. Red Book of Plants of the Republic of Armenia. 2010.

15. Sarker SD, Zahid L, Gray Al. Natural products isolation. Volume 20. Springer Science \& Business Media; 2005.

16. Sheehan DJ, Brown SD, Pfaller MA, Warnock DW, Rex JH, Chaturvedi V, et al. Method for Antifungal Disk Diffusion Susceptibility Testing of Yeasts; Approved Guideline. NCCLS. 2004.

17. Ginovyan M, Keryan A, Bazukyan I, Ghazaryan P, Trchounian A. The large scale antibacterial, antifungal and anti-phage efficiency of Petamcin-A: new multicomponent preparation for skin diseases treatment. Ann Clin Microbiol Antimicrob. 2015;14:28. Available from: http://www.ann-clinmicrob.com/ content/14/1/28.

18. Wiegand I, Hilpert K, Hancock REW. Agar and broth dilution methods to determine the minimal inhibitory concentration (MIC) of antimicrobial substances. Nat Protoc. 2008;3:163-75. Available from: http://www.nature. com/doifinder/10.1038/nprot.2007.521.

19. Cos P, Vlietinck AJ, Berghe DV, Maes L. Anti-infective potential of natural products: How to develop a stronger in vitro "proof-of-concept". J Ethnopharmacol. 2006;106:290-302.

20. Harutyunyan H. Herbs from Armenian medieval medical guides. Yerevan: Luys; 1990.

21. Torosyan A. Armenian herbs. Yerevan: Hayastan; 1983.
22. Dall'Agnol R, Ferraz A, Bernardi AP, Albring D, Nör C, Sarmento L, et al. Antimicrobial activity of some Hypericum species. Phytomedicine. 2003;10: 511-6.

23. Saddiqe Z, Naeem I, Maimoona A. A review of the antibacterial activity of Hypericum perforatum L. J Ethnopharmacol. Elsevier Ireland Ltd; 2010;131: 511-21. Available from: http://dx.doi.org/10.1016/j.jep.2010.07.034

24. Dulger B, Gonuz A. Antimicrobial activity of some Turkish medicinal plants. Pak J Biol Sci. 2004;7:1559-62.

25. Kokoska L, Polesny Z, Rada V, Nepovim A, Vanek T. Screening of some Siberian medicinal plants for antimicrobial activity. J Ethnopharmacol. 2002; 82:51-3.

26. Shan B, Cai YZ, Brooks JD, Corke H. The in vitro antibacterial activity of dietary spice and medicinal herb extracts. Int J Food Microbiol. 2007;117: $112-9$.

27. Wegiera M, Kosikowska U, Malm A, Smolarz HD. Antimicrobial activity of the extracts from fruits of Rumex L. species. Cent Eur J Biol. 2011;6:1036-43.

28. Copland A, Nahar L, Tomlinson CTM, Hamilton V, Middleton M, Kumarasamy $Y$, et al. Antibacterial and free radical scavenging activity of the seeds of Agrimonia eupatoria. Fitoterapia. 2003;74:133-5.

29. Watkins F, Pendry B, Sanchez-Medina A, Corcoran O. Antimicrobial assays of three native British plants used in Anglo-Saxon medicine for wound healing formulations in 10th century England. J Ethnopharmacol. 2012;144:408-15. Available from: http://dx.doi.org/10.1016/j.jep.2012.09.031

30. Cwikla C, Schmidt K, Matthias A, Bone KM, Lehmann R, Tiralongo E. Investigations into the Antibacterial Activities of Phytotherapeutics against Helicobacter pylori and Campylobacter jejuni. Phytother Res. 2010;24:649-56.

31. Mothana RA, Lindequist U. Antimicrobial activity of some medicinal plants of the island Soqotra. J Ethnopharmacol. 2005;96:177-81.

32. Barbour EK, Al Sharif M, Sagherian VK, Habre AN, Talhouk RS, Talhouk SN. Screening of selected indigenous plants of Lebanon for antimicrobial activity. J Ethnopharmacol. 2004;93:1-7.

33. Das K, Tiwari RKS, Shrivastava DK. Techniques for evaluation of medicinal plant products as antimicrobial agents: current methods and future trends. $J$ Med Plants Res. 2010;4:104-11. Available from: http://www. academicjournals.org/JMPR/PDF/pdf2010/18Jan/Dasetal.pdf.

\section{Submit your next manuscript to BioMed Central and we will help you at every step:}

- We accept pre-submission inquiries

- Our selector tool helps you to find the most relevant journal

- We provide round the clock customer support

- Convenient online submission

- Thorough peer review

- Inclusion in PubMed and all major indexing services

- Maximum visibility for your research

Submit your manuscript at www.biomedcentral.com/submit
) Biomed Central 